\title{
Pengaruh Umur dan Jenis Kelamin Terhadap Desain Tempat Kerja Pada Karyawan Perguruan Tinggi
}

\author{
P. Vitasari ${ }^{1 *}$, Dayal Gustopo ${ }^{2}$ \\ ${ }^{1,2}$ Teknik Industri, ITN Malang \\ *Email: primavitasari19@gmail.com
}

\begin{abstract}
Abstrak
Desain workplace berpengaruh pada penurunan kualitas pekerjaan, terutama diantara pekerja di industri. Hal ini juga berakibat tidak hanya pada menurunnya motivasi pekerja tapi juga kepuasan, hubungan social, performansi, dan kesehatan. Beberapa hasil penelitian mengungkapkan bahwa bekerja dalam kondisi tempat kerja yang aman dan sehat akan menunjang para karyawan bekerja secara total. Sehingga diperlukan inovasi untuk meningkatkan performansi karyawan. Inovasi ini berupa model untuk desain workplace yang disesuaikan dengan konsep green ergonomics guna meningkatkan human performance para karyawan. Di mana langkah awalnya berupa evaluasi desain workplace yang telah ada disesuaikan dengan kebutuhan karyawan. Oleh karena itu, pada penelitian ini dilakukan pengukuran pengaruh umur dan jenis kelamin terhadap desain tempat kerja pada karyawan Fakultas Teknologi Industri kampus 2 ITN Malang dengan menggunakan kuesioner. Sebanyak tiga puluh sembilan karyawan dilibatkan dalam pengumpulan data. Data yang telah terkumpul kemudian dilakukan analisis menggunakan statistic descriptive dan uji t SPSS 17 untuk mengetahui pengaruh pada variabel umur dan jenis kelamin. Hasil analisis pengaruh antara jenis kelamin dan umur terhadap workplace design, diperoleh koefisien $\mathrm{t}$ value sebesar 70,5\% dengan tingkat signifikan .000. dapat diartikan bahwa gender dan age memiliki pengaruh yang cukup tinggi terhadap workplace design. Hasil lain diperoleh dari analisis uji $\mathrm{t}$ (one sample t-test) untuk melihat pengaruh umur terhadap workplace design diperoleh koefisien $\mathrm{t}$ value sebesar $19.1 \%$ dengan tingkat signifikan .000 perempuan lebih menyukai soft color untuk ruang kerjanya sebanyak $60 \%$. Sedangkan laki-laki hanya merespon $40 \%$ terhadap pemilihan soft color. Sebaliknya, untuk ruang kerjanya laki-laki lebih dominan menyukai warna terang sejumlah 57\%, sedangkan perempuan yang menyukai warna terang hanya sebesar $43 \%$.
\end{abstract}

Kata Kunci: desain workplace, deskripsi statistic, ergonomi, jenis kelamin, uji t, karyawan perguruan tinggi.

\section{Pendahuluan}

Setiap institusi akan selalu berusaha untuk memaksimalkan potensi yang mereka miliki berupa sistem, proses dan sumberdaya manusia untuk mencapai hasil yang optimal. Ilmu dan pengetahuan tentang Human Performance Improvement (HPI) membantu lembaga-lembaga tersebut menjadi lebih baik dalam mencapai tujuan mereka terutama dalam upaya meningkatkan performansi dari karyawannya. Salah satu tujuan utama dari HPI adalah memberikan pengaruh positif secara langsung pada hasil ataupun produk suatu lembaga tersebut.

Hal serupa juga dikemukakan oleh beberapa peneliti diantaranya penelitian yang memfokuskan pada efek lingkungan bekerja pada job performance [1]. Penelitian tersebut mengungkapkan bahwa bekerja dalam kondisi tempat kerja yang aman dan sehat akan menunjang para karyawan bekerja secara total [1].

Teknologi yang mendukung serta informasi-informasi yang terbuka memberikan kemungkinan untuk menciptakan kondisi nyaman seperti adanya pendingin ruangan, desain ruangan yang tidak bising, sirkulasi udara cukup, pencahayaan, dan area kerja yang memadai. Faktor-faktor tersebut diharapkan mampu mengoptimalkan performansi dari para karyawan. 
Dalam sebuah penelitian, suatu perusahaan asuransi melakukan redesain terhadap fasilitas kerja dengan furnitur ergonomis. Hasil yang diperoleh dapat meningkatkan kinerja sebesar 10 sampai 15 persen [2]. Selain itu, tenaga kerja saat ini percaya bahwa lingkungan kerja yang bising menghambat kerja yang efektif. Hasil perhitungan statistik dari Asosiasi Manajemen Data menunjukkan bahwa kurangnya privasi akustik di kantor terbuka dapat menurunkan produktivitas sebanyak 40 persen dan meningkatkan kesalahan sebanyak 27 persen [3].

Berdasarkan uraian di atas, idealnya sebuah tempat kerja adalah memberikan kenyamanan, keamanan, kepuasan, hubungan social yang baik serta kesehatan bagi para karyawannya. Lembaga yang mempertimbangkan faktor-faktor ergonomis dalam pengaturan workplace sesungguhnya sebagai salah satu cara dalam memberikan penghargaan kepada para karyawannya supaya termotivasi dan lebih produktif.

Displin ilmu ergonomi saat ini sudah melibatkan global konten seperti sustainability/berkelanjutan, perubahan lingkungan, dan istilah-sitilah alamiah lainya [4;5]. Paparan mengenai hubungan interaksi antara alam dengan manusia akan bermanfaat bagi kesehatan dan kesejahteraan [6]. Konsep nature disajikan sebagai paradigma baru untuk ergonomi. Sebagai disiplin ilmu yang berkaitan dengan kesejahteraan, pentingnya lingkungan alam untuk kesehatan harus menjadi bagian dari pengetahuan dan praktek ilmu ergonomi. Posisi ini didukung dengan memberikan ringkasan singkat dari bukti nilai lingkungan alam untuk kesejahteraan [5], seperti efek pencahayaan, selain itu ada efek penting dari suhu dan kelembaban yang mempengaruhi lelah seseorang dalam bekerja, saat ini tidak ada peraturan yang mengatur tingkat suhu tinggi di tempat kerja dan tanggung jawab perusahaan kepada karyawan mereka dalam hal ini , meskipun Organisasi Kesehatan Dunia merekomendasikan suhu kerja maksimum dari $24^{\circ} \mathrm{C}$ [7]. Selanjutnya, sebuah penelitian telah menemukan hubungan antara kesejahteraan dan koneksi terhadap alam, dengan penjelasan bahwa sebuah konsep yang mengungkapkan karakter integratif pengalaman manusia yang dapat menginformasikan praktek yang lebih luas dan epistemologi secara mendalam [4]. Para praktisi menyarankan untuk membawa konsep nature ke tempat kerja , sehingga ergonomi terus berkembang ke solusi berbasis alam seperti yang diungkapkan dalam konsep green ergonomics, dengan tetap mempertimbangkan konteks ekologi dan sosial saat ini.

\section{Metode Penelitian}

Jenis penelitian ini adalah penelitian survey yaitu suatu desain yang digunaan untuk penyelidikan informasi yang berhubungan dengan prevalensi, distribusi dan hubungan antar variabel dalam suatu populasi. Data yang diperoleh berupa informasi dari tindakan seseorang, pengetahuan, kemauan, pendapat, perilaku, dan nilai. Jumlah keseluruhan populasi dan juga sampel adalah 39, terdiri dari karyawan tetap dan kontrak.

Instrument penelitian yang digunakan adalah inspection checklist yang disebut dengan $\mathrm{OH} \& \mathrm{~S}$ inspection. Terdapat tiga belas indikator dengan jumlah pertanyaan sebanyak tujuh puluh lima butir. Dalam checklist ini ada dua pilihan jawaban yaitu ya dan tidak. Instrument ini sudah diterjemahkan dalam bahasa Indonesia dengan tujuan memudahkan responden dalam menjawab pertanyaan.

Pengumpulan data dilakukan saat karyawan istirahat bekerja sehingga tidak mengganggu pekerjaanya. Dibutuhkan kurang lebih 15-20 menit dalam mengisi OH\&S inspection tersebut. Sebelumnya telah dilakukan tes validitas dan reliabilitas terhadap instrument OH\&S inspection. Kemudian untuk data wawancara dilakukan setelah pengisian OH\&S inspection ini untuk mengkonfirmasi beberapa pertanyaan yang diperlukan penjelasan setelah data terkumpul, kemudian dilakukan tabulasi data dan selanjutnya menganalisis data menggunakan deskriptif statistic untuk mengetahui kontribusi pada masing-masing indikator. Untuk menganalisis data digunakan SPSS 17.

\section{Hasil}

Kuesioner telah diuji secara reliabilitas dan validitas [8], Tabel berikut menunjukan hasil analisis hubungan antara gender dan usia terhadap workplace design. Age dan gender sebagai variable 
independent, sedangkan workplace design sebagai variable dependent. Analisis yang digunakan adalah uji t (one sample t-test), dengan tujuan untuk memperoleh koefisien t value pada pengaruh masingmasing variable bebas. Hasil analisis pengaruh antara jenis kelamin dan umur terhadap workplace design, diperoleh koefisien t value sebesar 70,5\% dengan tingkat signifikan .000. dapat diartikan bahwa jenis dan umur memiliki pengaruh yang cukup tinggi terhadap workplace design.

Hasil lain diperoleh dari analisis uji t (one sample t-test) untuk melihat pengaruh umur terhadap workplace design diperoleh koefisien $\mathrm{t}$ value sebesar $19.1 \%$ dengan tingkat signifikan .000 , diartikan jika usia memiliki pengaruh signifikan terhadap workplace design meskipun hanya bernilai kecil. Seperti pada table berikut :

Tabel 1. Pengaruh Antara Gender Dan Usia Terhadap Workplace Design

\begin{tabular}{|c|c|c|c|c|}
\hline Deskripsi & Mean & $\begin{array}{c}\text { Standard } \\
\text { deviation }\end{array}$ & $\begin{array}{c}\text { Coefficient } \\
(\boldsymbol{t} \text { value })\end{array}$ & $\begin{array}{c}\text { Sign } \\
(\boldsymbol{p} \text { value })\end{array}$ \\
\hline Gender & 3.11 & 1.092 & & \\
\hline Usia & 1.44 & .503 & & \\
\hline Workplace design & 17.04 & 1.621 & & \\
\hline Usia terhadap workplace design & & & 19.116 & .000 \\
\hline Gender dan usia terhadap workplace design & & & 70.532 & .000 \\
\hline
\end{tabular}

*t-test is significant at the 0.05 level

Sedangkan jika dilakukan analisis terpisah pada variable gender terhadap workplace design maka diperoleh jika staf laki-laki lebih berkontribusi pada workplace design dengan koefisien $55.01 \%$ dan tingkat signifikan .000 . Respon dari staf wanita sedikit lebih rendah dengan koefisien $53.21 \%$ dan tingkat signifikan .000 , seperti ditampilkan pada table berikut :

Tabel 2 Perbedaan Jenis Kelamin dalam Menyikapi Workplace Design

\begin{tabular}{|c|c|c|c|}
\hline Jenis kelamin & Mean & $\begin{array}{c}\text { Coefficient } \\
(\text { t value })\end{array}$ & $\begin{array}{c}\text { Sign } \\
(\boldsymbol{p} \text { value })\end{array}$ \\
\hline Laki-laki & 16.67 & 55.011 & .000 \\
\hline Perempuan & 16.89 & 53.217 & .000 \\
\hline
\end{tabular}

*t-test is significant at the 0.05 level

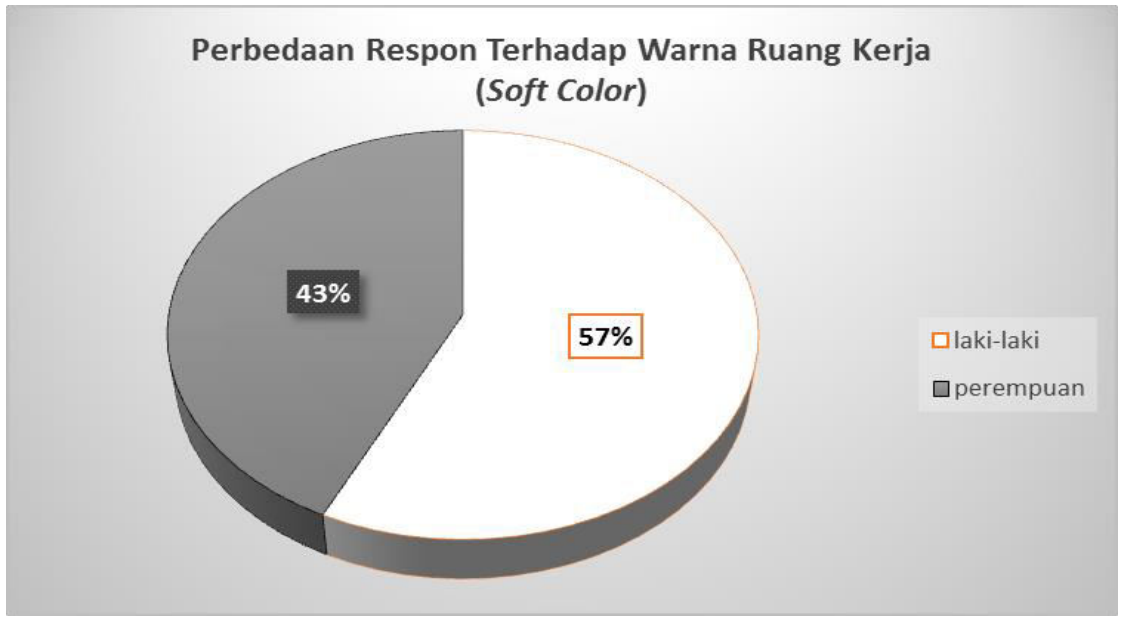

\section{Gambar 1. Perbedaan Respon Gender Dalam Pemilihan Warna Ruang Kerja (Soft Color)}

Gambar 1 menunjukkan respon laki-laki dan perempuan dalam memilih warna ruang kerja, hasil penelitian menunjukkan bahwa perempuan lebih menyukai soft color untuk ruang kerjanya sebanyak $60 \%$. Sedangkan laki-laki hanya merespon $40 \%$ terhadap pemilihan warna soft untuk ruang kerjanya. Hal ini menunjukkan karakter perempuan yang lebih menyukai warna-warna lembut dibanding laki-laki. Menurut hasil wawancara dengan beberapa respoden bahwa warna lembut akan memberikan inspirasi dan motivasi dalam bekerja. 


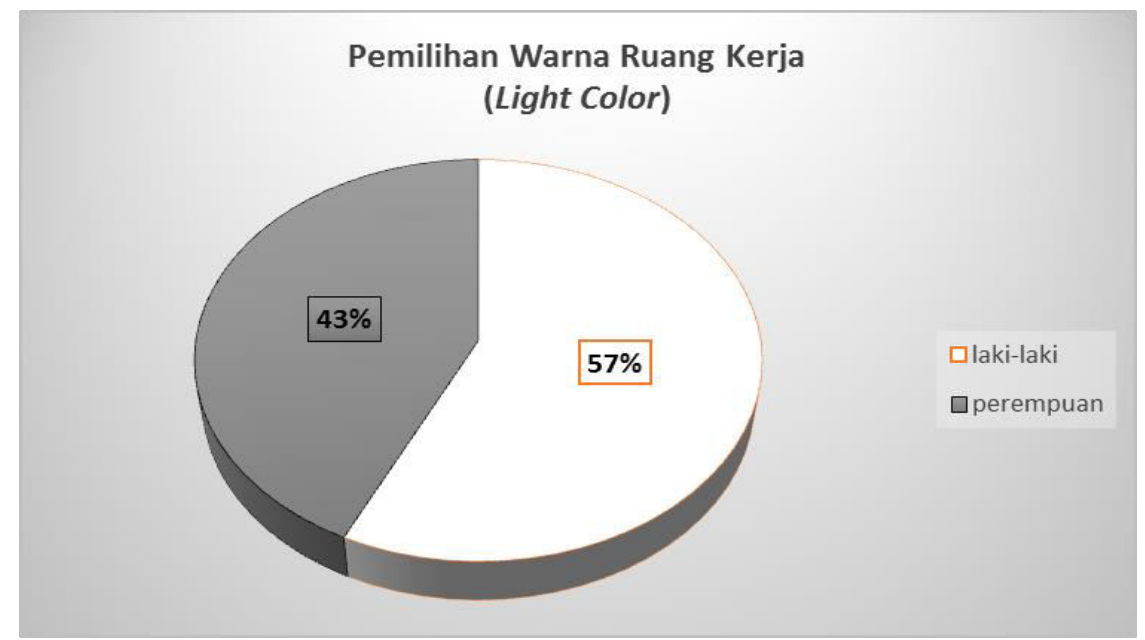

\section{Gambar 2. Perbedaan Respon Gender Dalam Pemilihan Warna Ruang Kerja (Light Color)}

Gambar 2 menunjukkan perbedaan respon laki-laki dan perempuan dalam pemilihan warna ruang kerja light color. Pada pemilihan light color laki-laki lebih dominan menyukai warna terang sejumlah $57 \%$, sedangkan perempuan yang menyukai warna terang hanya sebesar $43 \%$. Sebagian perempuan menyukai warna terang dengan anggapan lebih membawa suasana kerja yang ceria dan bersemangat.

\section{Kesimpulan}

Suatu tempat kerja harus mampu menciptakan kondisi nyaman seperti adanya pendingin ruangan, desain ruangan yang tidak bising, sirkulasi udara cukup, pencahayaan, dan area kerja yang memadai. Faktor-faktor tersebut diharapkan mampu mengoptimalkan performansi dari para karyawan. Para praktisi menyarankan untuk membawa konsep nature ke tempat kerja, sehingga ergonomi terus berkembang ke solusi berbasis alam atau konsep green ergonomics, tetapi juga mempertimbangkan konteks ekologi dan sosial saat ini. Hasil penelitian ini turut memberikan sumbangan pengetahuan tentang keilmuan di bidang teknik industri, bahwa suatu desain tempat kerja selayaknya dilakukan evaluasi secara berkala. Respon dari jenis kelamin dan juga umur menggambarkan bahwa masingmasing memberikan pengaruh yang signifikan terhadap desain tempat kerja yang konstan atau tidak ada perubahan dalam jangka waktu lama. Begitu juga mengenai warna cat ruangan yang jarang sekali dilakukan redesain sehingga warna yang lama sudah terlihat kusam. Pengecatan ulang juga dianggap sebagai satu motivasi dan semangat dalam bekerja. Saran yang ingin disampaikan bahwa restruktur serta redesain tempat kerja selayaknya terjadwal untuk dilakukan sehingga karyawan tidak merasa bosan dan jenuh.

\section{Daftar Refrensi}

[1] Abdul Rahman. A.B. 2012. A Theoretical Framework and Analytical Discussion on Uncongenial Physical Workplace Environment and Job Performance among Workers in Industrial Sectors. Procedia - Social and Behavioral Sciences. 42. Pp 486 - 495

[2] Rasha, M. A. E. 2012. The Interior Design of Workplace and its Impact on Employees' Performance: A Case Study of the Private Sector Corporations in Egypt. Procedia - Social and Behavioral Sciences. 35. Pp $746-756$

[3] McLaughlin, C. 2000. Sound Solutions. ASID ICON June.

[4] Thatcher, A. 2012. Green ergonomics, definition and scope. Ergonomics, Taylor and Francis. 56 (3). Pp 389-398.

[5] Miles, R. Marta, M. David, G. David S · Vicki S, and Ryan L. 2016. Nature: A New Paradigm for Well-being and Ergonomics. Ergonomics, Taylor and Francis. 
[6] Sandifer, P.A Ariana E. Sutton-Grier, and Bethney P. 2014. Ward Exploring connections among nature, biodiversity, ecosystem services, human health and well-being: Opportunities to enhance health and biodiversity conservation

[7] Kathy F. Montgomery. 2004. Understanding the Relationship between the Design of the Workplace Environment and Wellness. Texas Tech University.

[8] P. Vitasari, Dayal Gustopo, and Budi Fathoni. 2017. Workplace Instruments for Reliability and Validity Test among University Occupation. Proceeding International conference ICITSD, UMI Makassar. 